Review Article

\section{Orofacial manifestations of COVID-19}

\author{
Hariharan Ramakrishnan ${ }^{1 *}$ and Maniamuthu Ragupathi ${ }^{2}$ \\ ${ }^{1}$ Professor, Ragas Dental College \& Hospital, The TN Dr. MGR Medical University, Tamil Nadu, India \\ ${ }^{2}$ Lecturer, Ragas Dental College \& Hospital, Tamil Nadu, India
}

\section{Abstract}

Oral cavity is the gateway of the human body, and also provides vital clues of our systemic health. Here in this COVID-19 pandemic, oral manifestations such as dysgeusia, ulcers, xerostomia are noticed and are an an important predictors of this viral disease. This short review describes the oral manifestations of this new disease.

\section{Introduction}

COVID-19 is the viral pandemic that had created the medical emergency throughout the world especially with its severe form. This novel corona virus causes severe acute respiratory disease. The whole world had been under the search of an effective vaccine against this virus, which is a difficult task but not impossible, as it has mutated continuously throughout the current year into different strains that makes the treatment protocol to be modified. The common way of transmission is through salivary droplets. The diagnosis made through the nasopharyngeal and oropharyngeal samples that mainly depends on saliva. Symptoms such as fever, headache, dry cough, sore throat, dyspnea, abdominal pain, vomiting, and diarrhea are also common [1].

\section{Mechanism}

The SARS-COV-2 (severe acute respiratory syndromeCorona virus) mainly acts on Angiotensin converting enzyme 2 (ACE 2 ) receptors which are commonly present in lung, liver, kidney, endothelia of dermal papillary vessels and epithelium of sweat glands etc [2,3]. The attachment between the virus and ACE 2 receptors begins the inflammatory reaction and produces prostaglandins, leukotrienes, cytokines and other inflammatory mediators [2-4], these inflammatory reactions causes melanogenesis and lead to hyper pigmentation.

\section{Oral manifestations}

With regard to oral mucosa, ACE2 receptors are commonly seen in dorsum of tongue and salivary glands [2]. Immuno-inflammatory processes have been associated with hyperpigmentation of melanin from the oral mucosa [3]. Symptoms such as mucositis, candidiasis, HSV-1 (Herpes simplex virus) infections, petechiae, xerostomia, geographic

\author{
More Information \\ *Address for Correspondence: \\ Dr. Hariharan Ramakrishnan, Professor, Ragas \\ Dental College and Hospital, SH 49, East Coast \\ Road, Uthandi, Chennai-600119, Tamil Nadu, \\ India, Tel: 9841013590; \\ Email: abcv2005@yahoo.com \\ Submitted: May 01, 2021 \\ Approved: May 11, 2021 \\ Published: May 12, 2021 \\ How to cite this article: Ramakrishnan $\mathrm{H}$, \\ Ragupathi M. Orofacial manifestations of \\ COVID-19. J Oral Health Craniofac Sci. 2021; 6: \\ 006-007. \\ DOI: 10.29328/journal.johcs.1001034 \\ ORCiD: orcid.org/0000-0003-4466-5744 \\ Copyright: @ 2021 Ramakrishnan H, et al. \\ This is an open access article distributed under \\ the Creative Commons Attribution License, \\ which permits unrestricted use, distribution, \\ and reproduction in any medium, provided the \\ original work is properly cited. \\ Keywords: COVID-19; Oral manifestations; \\ Xerostomia; Angiotensin-converting enzyme \\ D) Check for updates \\ OPEN ACCESS
}

tongue, dysgeusia do occur. The oral manifestations can be appreciated through two ways. One may be direct sequelae of COVID-19 infection and the other may be secondary to suppression of human immune system or adverse effects of potential therapeutic drugs given for COVID-19 treatment $[4,5]$.

Based on these two considerations, xerostomia and dysgeusia falls into first category. As the salivary glands with ACE2 host cells are infected, the flow and consistency of saliva becomes reduced and thick which may also paves the way for altered taste sensation [5,6]. The taste disorder is the early symptom in most of the patients with COVID-19 infection that can occur due to binding of SARS-COV-2 with salivary mucin and ACE2 receptors and affects the normal gustatory functions [5,7-9]. Mucositis is also a very common symptom acquired as a result of thrombotic vasculopathy and vasculitis [10]. Salivary gland could be important source of COVID virus in saliva Positivity rate as high as $91.7 \%$ had also been reported $[11,12]$.

In course of treatment, drugs such as azithromycin, hydrochloroquine sulphate, sulphamethoxazole and trimethoprim, enaxoparin sodium, meropenam, ceftriaxone sodium, which may cause adverse effects and reduces 
immunity that may lead to secondary conditions like geographic tongue, Melkerson-Rosenthal syndrome, postinflammatory pigmentation of gingiva, opportunistic infections such as oral thrush, Herpes Simplex Virus (HSV) infection, angina bullosa like lesions can also occur $[2,8]$.

\section{Discussion}

Mucocutaneous lesions had been reported as part of MIS-C (Multisystem inflammatory syndrome in children [13]. COVID tongue in the form of discolouration, enlargement along with strange mouth ulcers had been reported in UK in early 2021 [14]. Rhino orbital mucormycosis had been reported as a severe fungal complication especially in older diabetic covid positive patient from India [15].

Within the available scientific literature on oral COVID manifestations, salivary diagnosis and oral symptoms are important predictors for this viral disease. Therapy for oral conditions is much more important not only during the COVID-19 treatment but also 1-2 weeks after the recovery from the disease [16]. Drugs such as fluconazole, nystatin, acyclovir should be prescribed for oppurtunistic infections. Artificial saliva can be suggested to manage xerostomia and oral hygiene measures such as use of chlorhexidine mouth washes, frequent change of tooth brush, and immersing the brush in $5 \%$ sodium hypochlorite solution for 30 minutes after every use should be advised [16,17].

\section{Conclusion}

In the current COVID-19 pandemic situation, dentists also have an important role to diagnose predisposing factors and treat oppurtunistic infections not only for this particular disease but also in limiting the spread of COVID infection by encouraging teleconsultation to identify proper patient selection for dental treatment and in implementing CDC (Centre for Disease Control- USA) guidelines and infection control protocol in day to day dental practice $[1,18]$. Teleconsulation is a mode of digital consolation enabled by way of various dedicated apps and through various hospital linked websites where the patient can fix up an online appointment with doctors for regular and extensive consultation. These digital sites are also enabled with links for uploading latest lab and radiographic reports of patients. Prescriptions are sent to patient's email and a copy is also available on the patient online account.

\section{References}

1. World Health Organization. (2019) Novel coronavirus (2019-nCoV) situation report - 22. 2020. https://www.who.int/docs/default-source/ coronaviruse/situation-reports/20200211-sitrep-22-ncov.pdf?

2. Riad A, Klugar M, Krsek M. COVID-19-Related Oral Manifestations: Early Disease Features. Oral Dis. 2020; 10.1111/odi.13516.

PubMed: https://pubmed.ncbi.nlm.nih.gov/32603497/
3. Amorim Dos Santos J, Normando AGC, Carvalho da Silva RL, De Paula RM, Cembranel AC, et al. Oral mucosal lesions in a COVID-19 patient: New signs or secondary manifestations? Int J Infect Dis. 2020; 97: 326-328.

PubMed: https://pubmed.ncbi.nIm.nih.gov/32526392/

4. Chandran R, Feller L, Lemmer J, Khammissa RAG. HIV-associated oral mucosal melanin hyperpigmentation: a clinical study in a South African population sample. AIDS Res Treat. 2016; 8: 1-5. PubMed: https://pubmed.ncbi.nIm.nih.gov/27006825/

5. Finsterer J, Stollberger C. Causes of hypogeusia/hyposmia in SARSCoV2 infected patients. J Med Virol. 2020; 92: 1793-1794.

PubMed: https://pubmed.ncbi.nlm.nih.gov/32311107/

6. Saniasiaya J. Xerostomia and COVID-19: Unleashing Pandora's Box. Ear Nose Throat J. 2021; 100(2 suppl):139S. PubMed: https://pubmed.ncbi.nIm.nih.gov/32955342/

7. Corchuelo J, Ulloa FC. Oral manifestations in a patient with a history of asymptomatic COVID-19: Case report. Int J Infect Dis. 2020; 100: 154-157.

PubMed: https://pubmed.ncbi.nlm.nih.gov/32882435/

8. Martín Carreras-Presas C, Amaro Sánchez J, López-Sánchez AF, Jané-Salas E, Somacarrera Pérez ML. Oral vesiculobullous lesions associated with SARS-CoV-2 infection. Oral Dis. 2020; 27 Suppl 3: 710-712.

PubMed: https://pubmed.ncbi.nlm.nih.gov/32369674/

9. Lozada-Nur F, Chainani-Wu N, Fortuna G, Sroussi H. Dysgeusia in COVID-19: Possible Mechanisms and Implications. Oral Surg Oral Med Oral Pathol Oral Radiol. 2020; 130: 344-346. PubMed: https://pubmed.ncbi.nlm.nih.gov/32703719/

10. Chaux-Bodard AG, Deneuve S, Desoutter A. Oral manifestation of Covid-19 as an inaugural symptom? J of Oral Med Oral Surg. 2020; 26: 18. DOI: https://doi.org/10.1051/mbcb/2020011; https://www.jomos.org/articles/mbcb/full_html/2020/02/mbcb200030/ mbcb200030.html

11. Liu L, Wei Q, Alvarez X, Wang H, Du Y, et al. Epithelial cells lining salivary gland ducts are early target cells of severe acute respiratory syndrome coronavirus infection in the upper respiratory tracts of rhesus macaques. J Virol. 2011; 85: 4025-4030.

PubMed: https://pubmed.ncbi.nlm.nih.gov/21289121/

12. To KK, Tsang OT, Yip CC, Chan KH, Wu TC, et al. Consistent Detection of 2019 Novel Coronavirus in Saliva. Clinical infectious diseases: an official publication of the Infectious Diseases Society of America. 2020; 71: 841-843.

PubMed: https://pubmed.ncbi.nlm.nih.gov/32047895/

13. Nalbandian A, Sehgal K, Gupta A, Madhavan MV, McGroder C, et al. Post-acute COVID-19 syndrome. Nature medicine. 2021; 27:601-615. PubMed: https://pubmed.ncbi.nlm.nih.gov/33753937/

14. https://www.webmd.com/lung/news/20210129/covid-tongue-may-bea-symptom-professor-says

15. Mehta S, Pandey A. Rhino-Orbital Mucormycosis Associated With COVID-19. Cureus. 2020; 12: e10726.

PubMed: https://www.ncbi.nlm.nih.gov/pmc/articles/PMC7599039/

16. Iranmanesh $B$, Khalili $M$, Amiri $R$, Zartab $H$, Aflatoonian $M$. Oral manifestations of COVID-19 disease: A review article. Dermatol Ther. 2021; 34: e14578.

PubMed: https://pubmed.ncbi.nlm.nih.gov/33236823/

17. Maciel PP, Martelli Júnior H, Martelli DRB, Machado RA, Andrade PV, et al. COVID-19 pandemic: oral repercussions and its possible impact on oral health. Pesqui Bras Odontopediatria Clín Integr. 2020; 20(supp1): e0138.

18. Sabino-Silva R, Jardim ACG, Siqueira WL. Coronavirus COVID-19 impacts to dentistry and potential salivary diagnosis. Clin Oral Investig. 2020; 24: 1619-1621.

PubMed: https://pubmed.ncbi.nIm.nih.gov/32078048/ 